\title{
Dimensi Struktur Modal pada Perusahaan Property and Real Estate
}

\author{
Fida Nur Annisa \\ Universitas Islam Batik Surakarta \\ Fidafid20@gmail.com
}

\author{
Yuli Chomsatu Samrotun \\ Universitas Islam Batik Surakarta \\ chom_satoe@gmail.com
}

\author{
Rosa Nikmatul Fajri \\ Universitas Islam Batik Surakarta \\ rosanikmatulfajrimail@ugm.ac.id
}

Corresponding Author : Fida Nur Annisa

Submitted: 7 Januari 2020

Accepted: 16 Juni 2020

Published: 1 Agustus 2020

\section{ABSTRACT}

Capital structure is a balance or comparison between foreign capital and own capital. This study aims to examine and analyze the effect of profitability, non-debt tax shield, asset structure, company size, and liquidity in property and real estate companies in 2015-2018. The independent variables of this study are profitability, non-debt tax shield, asset structure, company size, and liquidity. The dependent variable in this study is the capital structure. This study uses secondary data obtained from the IDX. With a population of 48 property and real estate manufacturing companies and sampling techniques using purposive sampling produces 32 sample companies. This type of quantitative research and data analysis techniques using multiple linear regression. The results of the research partially addressed the variable profitability, company size and liquidity which had no significant effect on capital structure while the non-debt tax shield and asset structure variables had a significant effect on capital structure.

Keywords : Profitability, NDTS, Asset Structure, Size, Likuidity, Capital Structure

\section{PENDAHULUAN}

Investasi dalam bidang industri property and real estate termasuk dalam investasi jangka panjang dan akan terus tumbuh seiring dengan pertumbuhan ekonomi serta diyakini suatu investasi yang menjanjikan. Industri real estate dan property ialah industri yang bergerak pada bidang pengembang jasa dal, pembangunan kawasan terpadu dan modern (Tangkulung, Murni, \& Untu, 2019). Produk yang dihasilkan oleh industri property dan real estate seperti landed property (perumahan, apartment, ruko, hotel dan gedung perkantoran) dan commercial building ( mall, plaza, atau trade center).

Peran seorang manajer keuangan didalam sebuah perusahaan dihadapkan pada keputusan penting yang berdampak pada nilai perusahaan. Keputusan keputusan tersebut adalah pertama, keputusan investasi yang berkaitan dengan masalah bagaimana manajer keuangan mengelola dana yang dimiliki perusahaan dalam bentuk investasi untuk mendapatkan keuntungan dimasa mendatang. Yang kedua yaitu keputusan pendanaan, keputusan ini harus diambil oleh seorang manajer keuangan untuk 
menyeimbangkan sumber - sumber dana perusahaan agar mendapat komposisi yang optimal di perusahaan. Struktur Modal adalah kombinasi dari keseluruhan hutang perusahaan terhadap modal perusahaan.

Keputusan pendanaan dilakukan perusahaan kurang cermat akan membuat biaya tetap dapat mebentuk biaya yang tinggi, yang selanjutnya akan berdampak pada profitabilitas yang rendah. Keputusan pendanaan berarti berkaitan dengan modal atau dana yang ada dalam perusahaan. Sumber pendanaan bisa bersumber dari eksternal ataupun internal, sumber pendanaan internal bisa diperoleh dari arus kas atau laba ditahan, diperoleh dari akumulasi keuntungan periode sebelumya, sedangkan pendanaan eksternal berasal dari pinjaman atau penggunaan utang.

Dalam penelitian ini ada lima faktor yang mempengaruhi struktur modal dan beberapa hasil penelitian yang melatarbelakangi penelitian ini berkaitan dengan faktor yang mempengaruh struktur modal dengan menunjukan hasil yang berbeda.

Variabel Pertama adalah profitabilitas. Penelitian dilakukan oleh (Putri \& Dillak, 2018), (Thabet, Shawtari, Mohammed, \& Ali, 2017) menunjukan hasil yang sama bahwa profitabilitas tidak ada pengaruh terhadap struktur modal. Namun peneliti lain dengan hasil yang berbeda ditujukan oleh peneliti (Wirawan, 2017), (Goh, Tai, Rasli, Tan, \& Zakuan, 2018), (Andayani \& Suardana, 2018) menunjukan hasil yang sama bahwa profitabilitas tidak ada pengaruh terhadap struktur modal., Penelitian ini sejalan dengan (Sudiyanto, Irmawati, Puspitasari, \& Nurhayati, 2019) dan (Kartika Sari, Titisari, \& Nurlaela, 2018).

Variabel kedua adalah non-debt tax shield. Penelitian dilakukan oleh (Putri \& Dillak, 2018), (Wulandari \& Artini, 2019) menunjukan hasil yang sama bahwa non-debt tax shield tidak ada pengaruh terhadap struktur modal. Namun hasil penelitian lain yang berbeda ditunjukan oleh peneliti Goh et al., (2018), (Dewi, Susyanti, \& Salim, 2018) menunjukan hasil yang sama bahwa nondebt tax shield ada pengaruh terhadap struktur modal, penelitian ini sejalan dengan (Krisnanda \& Wiksuana, 2015), (Nainggolan, Azlina, \& Julita, 2017).

Variabel yang ketiga yaitu struktur aktiva (aset. Penelitian dilakukan oleh (Kartika Sari, Titisari, \& Nurlaela, 2018), (Sudiyanto, Irmawati, Puspitasari, \& Nurhayati, 2019), (Andayani \& Suardana, 2018) menunjukan hasil yang sama bahwa struktur aktiva tidak ada pengaruh terhadap struktur modal. Namun hasil penelitian yang berbeda ditunjukan oleh (Ahmad, Lestari, \& Dalimuthe, 2017), (Wirawan, 2017) dengan menunjukan hasil yang sama bahwa struktur aktiva ada pengaruh terhadap struktur modal, penelitian ini sejalan dengan (Ariani \& Wiagustini, 2017) dan (Goh, Tai, Rasli, Tan, \& Zakuan , 2018).

Variabel kempat adalah ukuran perusahaan. Menurut penelitian yang dilakukan oleh (Wirawan, 2017), (Putri \& Dillak, 2018), (Kartika Sari, Titisari, \& Nurlaela, 2018) menunjukan hasil yang sama bahwa ukuran perusahaan tidak ada pengaruh terhadap struktur modal. Hasil penelitian lain yang berbeda ditunjukan oleh Ahmad et al., (2017), (Goh, Tai, Rasli, Tan, \& Zakuan, 2018), (Wulandari \& Artini, 2019), dengan menunjukan hasil sama bahwa ukuran perusahaan ada pengaruhnya terhadap struktur modal, penelitian ini sejalan dengan (Ariani \& Wiagustini, 2017) dan (Sundari \& Susilowibowo, 2016 ).

Faktor kelima adalah likuiditas. Menurut penelitian yang dilakukan oleh (Wirawan, 2017), (Dewi, Susyanti, \& Salim, 2018), (Andayani \& Suardana, 2018) dengan menunjukan hasil yang sama bahwa likuiditas tidak ada pengaruh terhadap struktur modal. Namun hasil penelitian yang berbeda 
ditunjukan oleh (Ahmad, Lestari, \& Dalimuthe, 2017), (Goh, Tai, Rasli, Tan, \& Zakuan, 2018), (Sudiyanto, Irmawati, Puspitasari, \& Nurhayati, 2019) dengan menunjukan hasil bahwa likuiditas ada pengaruhnya terhadap struktur modal, penelitian ini sejalan dengan (Kartika Sari, Titisari, \& Nurlaela, 2018) dan (Goh, Tai, Rasli, Tan, \& Zakuan, 2018).

Berdasar hasil penelitian yang telah disebutkan diatas menunjukan hasil kontradiktif dengan hasil penelitian yang ada. Dengan begitu peneliti ingin membuat penelitian baru tentang pengaruh profitabilitas, non-debt tax shield, struktur aktiva, ukuran perusahaan dan likuiditas terhadap struktur modal dengan studi kasus di perusahaan property and real estate. Tujuan penelitian ini untuk menguji serta menganislis pengaruh variabel profitabilitas, non-debt tax shield, struktur aktiva, ukuran perusahaan dan likuiditas terhadap struktur modal. Manfaat dari penelitian ini untuk menambah refrensi penelitian selanjutnya mengenai penelitian tentang pengaruh profitabilitas, non-debt tax shield, struktur aktiva, ukuranp erusahaan dan likuiditas terhadap strukturmodal.

\section{LANDASAN TEORI}

\subsection{Signalling Theory}

Menurut Brigham, et al., (2014) teori signaling adalah sebuah isyarat atau signal suatu tindakan yang digunakan perusahaan untuk memberikan petunjuk untuk para investor tentang bagaimana pengelolaan prospek manajemen keuangan perusahaan. Dalam struktur modal, sinyal berupa porsi hutang yang lebih besar di perusahaan. Jika utang yang dimiliki perusahaan tinggi, maka kemungkinan bangrut juga tinggi. Jika perusahaan mengalami kebangkrutan, manajer akan menerima dampaknya. Oleh karena itu, perusahaan yang berani menambah tingkat hutang akan dipandang sebagai perusahaan yang yakin dengan prospek yang baik dimasa mendatang. Karena dirasa cukup yakin dengan pengelolaan hutangnya dan mampu dalam pengembalian modal perusahaan. Investor diharapkan bisa menangkap sinyal tersebut, bahwa perusahaan mampu mengelola hutang dengan baik.

\subsection{Trade - Off Theory (Teori Pertukaran)}

Trade-off Theory menyatakan dimana perusahaan menukarkan pemanfaatan pajak dari pendanaan hutang apabila ada masalah yang ditimbulkan oleh potensi kebangkrutan. Teori trade-off mengemukakan bahwa perusahaan harus menyeimbangkan keuntungan dari pendanaan melalui hutang, yaitu tax shield dengan biaya hutang. Struktur Modal optimal yaitu bisa menyeimbangkan antara manfaat dan biaya dari penggunaan pembiayaan dari pinjaman. Menurut (Brigham \& Houston, 2011) Keseimbangan yang dimaksud yaitu pemanfaatan pajak yang diperoleh perusahaan dan biaya kebangkrutan.

\subsection{Pecking Order Theory}

Menurut (Ardiansyah \& Srimindarti, 2018) Pecking Order Theory merupakan kecenderungan perusahaan dalam menentukan pembiayaan berdasar sumber dana yang lebih disukai. Dimana perusahaan lebih lebih memilih pengunaan dana internal dahulu dan bila perusahaan kekurangan baru menggunakan pendaan eksternal. Perusahaan dengan tingkat laba yang tinggi lebih menyukai pemanfaatan pendanaan internal seperti laba ditahan jika dibandingkan dengan pendanaan eksternal.

\subsection{Struktur Modal}

Struktur modal ialah perimbangan antara hutang dan modal sendiri (Wiyono \& Kusuma, 2017 : 173). Dengan arti lain Struktur modal 
merupakan perimbangan modal asing dengan modal sendiri. Modal asing sendiri merupakan utang jangka panjang dan jangka pendek. Sedang, modal sendiri terdiri dari laba ditahan dan penyertaan kepemilikan modal perusahaan.

\subsection{Profitabilitas}

Menurut (Munawir, 2004 : 33) profitabilitas menunjukan bagaimana kemampuan perusahaan untuk memperoleh laba selama periode tertentu. Menurut pecking order theory, dimana perusahaan yang memiliki pendapatan yang besar akan memiliki laba ditahan yang tinggi. Perusahaan bisa menggunakan pendanaan melalui laba ditahan dahulu, apabila dirasa cukup untuk memenuhi kebutuhan modal perusahaan maka tidak perlu penggunaan dana dari eksternl atau hutang.

\subsection{Non-debt tax shield}

Menurut (Nainggolan , Azlina, \& Julita, 2017) Non - Debt Tax Shiled atau perlindungan pajak non utang, merupakan pengehematan pajak bukan dari utang, namun berupa pembebanan biaya depresiasi dan amortisasi terhadap laba rugi (Yoshendy, Andi, \& Dkk, 2015) . Non-debt tax shield memilki pengaruh terhadap struktur modal, dimana manfaat pengunaan hutang adalah bunga hutang yang dapat digunakan untuk mengurangi pembebanan pajak perusahaan.

\subsection{Struktur Aktiva}

Menurut (Brigham \& Weston, 2005:175) Struktur aktiva atau struktur kekayaan adalah perimbangan atau perbandingan antara aktiva lancar dengan aktiva tetap. Perusahaan memiliki proporsi struktur aktiva yang lebih besar kemungkinan akan menggunakan modal eksternal dalam struktur modalnya, sebuah perusahaan mempunyai struktur aktiva tinggi akan memberi sinyal positif kepada para kreditur.

\subsection{Ukuran Perusahaan}

Menurut Saidi, (2004) Size atau Ukuran perusahaan yakni ukuran atau besarnya asset yang dimiliki suatu perusahaan. Perusahaan besar juga butuh dana besar, maka pemenuhan kebutuhan dana perusahaan menggunakan utang. Dengan begitu ukuran perusahaan bisa dikatakan berpengaruh terhadap struktur modal. Besar kecilnya ukuran perusahaan mungkin berpengaruh terhadap struktur modal dengan semakin besarnya perusahaan maka akan memiliki tingkat pertumbuhan tinggi.

\subsection{Likuiditas}

Menurut (Van Horne \& Wachowich, 2001) likuditas adalah kemampuan perusahaan dalam pemenuhan kewajiban jangka pendeknya (hutang lancar) yang tersedia untuk memenuhi kewajiban. Apabila perusahaan memiliki likuiditas yang tinggi, cenderung tidak menggunakan pendanaan eksternal, karena perusahaan dengan tingkat likuiditas yang tinggi besar kemungkinan perusahaan tersebut mempunyai dana internal besar.

\subsection{Penelitian Sebelumnya}

Penelitian dilakukan oleh Ahmad, et al., (2017), Menunjukan hasil Profitabilitas memiliki pengaruh terhadap strukturmodal, Struktur Aktiva memiliki pengaruh terhadap struktur modal, Ukuranperusahaan memiliki pengaruh terhadap struktur modal, Likuiditas memiliki pengaruh terhadap struktur modal.

Penelitian dilakukan oleh Thabet, et al., (2017), Menunjukan hasil Pajak tidak berpengaruh terhadap struktur modal, non-debt tax shield tidak berpengruh signifikan, Profitabilitas tidak berpengaruh terhadap struktur modal, Struktur aset tidak berpangaruh terhadap struktur modal, Resiko bisnis memiliki pengaruh terhadap struktur modal.

Penelitian dilakukan oleh (Ariani \& Wiagustini, 2017), Menunjukan hasil 
Profitabilitas, struktur aktiva, peluang pertumbuhan, non-debt tax shield, ukuran perusahaan berpengaruh signifikan terhadap struktur modal.

Penelitian dilakukan oleh Kartika Sari, et al., (2018), Menunjukan hasil bahwa variabel Struktur aktiva, ukuran perusahaan, profitabilitas tidak berpengaruh terhadap struktur modal dan Likuiditas berpengaruh signifikan terhadap struktur modal struktur modal.

Penelitian dilakukan oleh Andayani, et al., (2018), Menunjukan hasil Profitabilitas berpengaruh signifikan terhadap struktur modal dan Likuidtas, pertumbuhan penjualan, struktur aktiva tidak berpengaruh signifikan terhadap struktur modal.

Penelitian dilakukan oleh Sudiyanto, et al., (2019) ,Menunjukan hasil bahwa variabel Struktur aktiva dan ukuran perusahaan tidak berpengaruh signifikan terhadap struktur modal dan variabel Profitabilitas dan likuiditas berpengaruh signifikan terhadap struktur modal.

\subsection{Kerangka Pemikiran}

Dibawah ini merupakan kerangka pemikiran dalam penelitian ini:

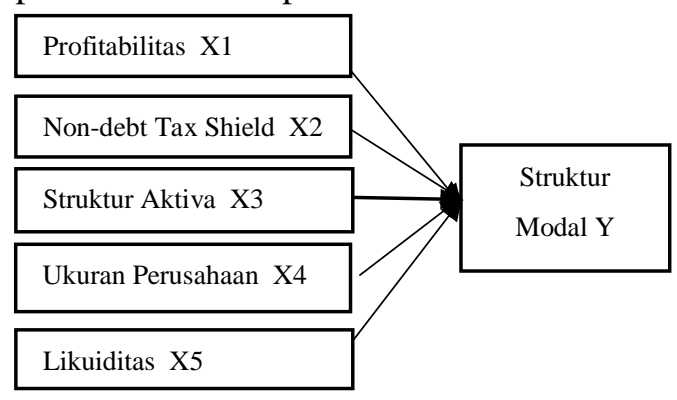

Gambar 1. Kerangka Berfikir

\subsection{Perumusan Hipotesis}

\subsubsection{Profitabilitas berpengaruh} terhadap struktur modal

Profitabilitas merupakan

kemampuan perusahaan untuk menghasilkan laba selama periode tertentu. Semakin tinggi nilai laba bersih yang dimiliki perusahaan, maka semakin tinggi juga profitabilitas yang akan dihasilkan perusahaan tersebut. Menurut penelitian (Wirawan, 2017) dan (Andayani \& Suardana, 2018) menunjukan hasil bahwa profitabilitas berpengaruh terhadap struktur modal.

H1 : Profitabilitas Berpengaruh terhadap struktur modal

\subsubsection{Non-debt tax shield} berpengaruh terhadap struktur modal Non-debt tax shield merupakan pengehematan pajak bukan berasal dari utang, namun berupa pembebanan biaya depresiasi terhadap total aset dan pengurangan pajak akibat penggunaan selain utang. Semakin tinggi depresiasi maka semakin tinggi pula aktiva tetap dan dana internal perusahaan. Menurut penelitian (Dewi \& Dana, 2017) dan (Ariani \& Wiagustini, 2017) menunjukan bahwa non-debt tax shiled berpengaruh terhadap struktur modal.

H2 : Non-debt tax shield berpengaruh terhadap struktur modal

\subsubsection{Struktur aktiva berpengaruh terhadap struktur modal}

Struktur aktiva (aset) yaitu perimbangan antara aktiva lancar dengan aktiva tetap yang dimiliki perusahaan. Perusahaan yang memiliki aset tetap yang tergolong besar dapat menggunakan utang yang lebih besar. Jadi, apabila struktur aktiva meningkat, maka struktur modal akan mengalami peningkatan. Menurut penelitian (Ariani \& Wiagustini, 2017) dan (Goh, Tai, Rasli, Tan, \& Zakuan , 2018) menunjukan bahwa struktur aktiva berpengaruh terhadap struktur modal.

H3 : Struktur aktiva berpengaruh terhadap struktur modal

\subsubsection{Ukuran perusahaan berpengaruh terhadap struktur modal Ukuran perusahaan atau size merupakan besar kecilnya ukuran perusahaan yang dilihat dari total aset perusahaan. Perusahaan besar akan cenderung menggunakan utang yang}


besar karena ukuran perusahaan dapat dijadikan jaminan untuk mendapatakan utang dari pihak luar. Menurut penelitian (Ahmad, Lestari, \& Dalimuthe, 2017) dan (Goh, Tai, Rasli, Tan, \& Zakuan, 2018) menunjukan hasil bahwa ukuran perusahaan atau size berepengaruh terhadap struktur modal.

H4 : Ukuran perusahaan berpengaruh terhadap struktur modal

\subsubsection{Likuiditas berpengaruh terhadap struktur modal}

Likuiditas yaitu kemapuan perusahaan dalam memenuhi kewajiban jangka pendeknya. Menurut pecking order theory perusahaan memiliki likuiditas yang tinggi akan cenderung tidak menggunakan pembiayaan dari hutang. Karena perusahaan dengan likuiditas yang tinggi mempunyai dana internal yang besar, sehingga perusahaan akan lebih menggunakan dana internal terlebih dahulu sebelum penggunaan dana eskternal. Menurut penelitain (Ardiansyah \& Srimindarti, 2018) dan (Goh, Tai, Rasli, Tan, \& Zakuan , 2018) menunjukan bahwa likuiditas berpengaruh terhadap struktur modal.

\section{H5 : Likuditas berpengaruh terhadap} struktur modal

\section{METODE PENELITIAN}

Penelitian ini termasuk penelitian kuantitatif. Sumber data adalah data sekunder dari data www.idx.co.id. Dengan jumlah populasi 48 perusahaan property and real estate yang terdafatar di BEI 2015-2018, pengambilan sampel dengan purposive sampling sesuai dengan kriteria menghasilkan 32 sampel perusahaan dan metode analisis dengan mengunakan analisis regresi linear berganda menggunakan SPSS Versi 22.
Variabel Penelitian dan

Pengukurannya

a. Struktur Modal (Y)

Variabel dependen dalam penelitian ini adalah struktur modal. diproksikan dengan DER, proksi ini juga digunakan (Kartika Sari, Titisari, \& Nurlaela, 2018).

\section{b. Profitabilitas (X1)}

$$
\text { DER }=\frac{\text { Total Hutang }}{\text { Total Ekuitas }}
$$

Variabel profitabilitas diproksikan dengan ROA, proksi ini juga digunakan (Andayani \& Suardana, 2018).

$$
\mathrm{ROA}=\frac{\text { Laba Setelah Pajak }}{\text { Total Aset }}
$$

\section{c. Non-debt Tax Shield (X2)}

Variabel Non debt diproksikan dengan depresiasi dibagi total aset, proksi ini juga digunakan (Ariani \& Wiagustini, 2017).

$$
\text { NDTS }=\frac{\text { Depresiasi }}{\text { Total Aset }}
$$

d. Struktur Aktiva (X3)

Variabel ini diproksikan dengan Fixed Asset Ratio (FAR), proksi ini juga digunakan (Kartika Sari, Titisari, \& Nurlaela, 2018).

$$
\text { FAR }=\frac{\text { Total Aktiva Tetap }}{\text { Total Aktiva }}
$$

e. Ukuran Perusahaan (X4)

Variabel ini diproksikan dengan Logaritma Natural (LN) terhadap total aset, proksi ini juga digunakan (Wirawan, 2017).

Ukuran Perusahaan

$$
=\text { Ln (Total Aset) }
$$

f. Likuiditas (X5)

Variabel ini di proksikan dengan Current Ratio (CR), proksi ini juga digunakan (Kartika Sari, Titisari, \& Nurlaela, 2018).

$$
\mathrm{CR}=\frac{\text { Total Aktiva Lancar }}{\text { Total Hutang Lancar }}
$$




\section{HASIL PENELITIAN DAN PEMBAHASAN}

\subsection{Deskripsi Umum Data penelitian}

Tabel 1: Pemilihan Sampel

\begin{tabular}{|c|c|c|}
\hline No & Kriteria & Jumlah \\
\hline 1 & $\begin{array}{l}\text { Perusahaan property and } \\
\text { realestate yang terdaftar di } \\
\text { Bursa Efek Indonesia } \\
\text { periode tahun 2015-2018 }\end{array}$ & 48 \\
\hline 2 & $\begin{array}{lr}\text { Perusahaan property and } \\
\text { real estate } & \text { secara } \\
\text { bertururut-turut } & \text { tidak } \\
\text { terdaftar di BEI periode } \\
2015-2018\end{array}$ & (4) \\
\hline 3 & $\begin{array}{l}\text { Perusahaan Property and } \\
\text { real estate tidak } \\
\text { menyampaikan laporan } \\
\text { keuangan tahunan secara } \\
\text { lengkap tahun 2015-2018 }\end{array}$ & (1) \\
\hline 4 & $\begin{array}{l}\text { Perusahaan property and } \\
\text { real estate yang mengalami } \\
\text { kerugian pada } 2015-2018\end{array}$ & (11) \\
\hline 5 & $\begin{array}{l}\text { Perusahaan property and } \\
\text { real estate yang tidak } \\
\text { menggunakan } \\
\text { mata uang rupiah }\end{array}$ & (0) \\
\hline 6 & $\begin{array}{l}\text { Jumlah perusahaan } \\
\text { yangmenjadisampel }\end{array}$ & 32 \\
\hline 7 & $\begin{array}{l}\text { Jumlah Observasi } \\
2015-2018(32 \times 4)\end{array}$ & 128 \\
\hline & Jumlah Sampel & 128 \\
\hline
\end{tabular}

Sumber : Data Diolah 2019

\subsection{HASIL PENELITIAN}

\subsubsection{Uji Asumsi Klasik}

\subsubsection{Uji Normalitas ( Kolmogorov-} Smirnov)

Uji Normalitas dengan metode Kolmogrov Semirnov, digunakan untuk menguji apakah residual yangdihasilakan terdistribusi normal

Tabel 3.: Hasil Uji Normalitas

\begin{tabular}{|c|c|c|c|c|}
\hline $\begin{array}{c}\text { Variabe } \\
\text { l }\end{array}$ & $\mathbf{N}$ & $\begin{array}{c}\text { Asymp } \\
\text {. Sig 2- } \\
\text { talied }\end{array}$ & Sig. & $\begin{array}{c}\text { Kesimpula } \\
\mathbf{n}\end{array}$ \\
\hline Ustd. & 12 & 0.200 & $>0.0$ & Data \\
\hline Residual & 8 & & 5 & $\begin{array}{c}\text { Terdistribusi } \\
\text { Normal }\end{array}$ \\
\hline
\end{tabular}

Sumber : Data Diolah 2019

\subsubsection{Uji Multikolinearitas}

Uji Multikolinearitas mengunakan nilai Variance Inflation Factor (VIF), berdasar pada tabel dibawah nilai toleransi $>0.10$ dari nilai VIF variabel $<10$, berarti tidak terjadi multikolinearitas.

Tabel 4.: Hasil Uji Multikolinearitas

\begin{tabular}{|c|c|c|c|c|c|}
\hline $\begin{array}{c}\text { Variabel } \\
\text { Independe } \\
\mathrm{n}\end{array}$ & $\begin{array}{c}\text { Tolera } \\
\text { nce }\end{array}$ & Std & VIF & Std & Keterangan \\
\hline ROA & 0.983 & $>0.10$ & $\begin{array}{l}1.01 \\
8\end{array}$ & $<10$ & $\begin{array}{c}\text { Tidak Terjadi } \\
\text { Multikolinearit } \\
\text { as }\end{array}$ \\
\hline NDTS & 0.962 & $>0.10$ & $\begin{array}{l}1.03 \\
9\end{array}$ & $<10$ & $\begin{array}{c}\text { Tidak Terjadi } \\
\text { Multikolinearit } \\
\text { as }\end{array}$ \\
\hline SA & 0.985 & $>0.10$ & $\begin{array}{l}1.01 \\
5\end{array}$ & $<10$ & $\begin{array}{c}\text { Tidak Terjadi } \\
\text { Multikolinearit } \\
\text { as }\end{array}$ \\
\hline SIZE & 0.978 & $>0.10$ & $\begin{array}{l}1.02 \\
2\end{array}$ & $<10$ & $\begin{array}{l}\text { Tidak Terjadi } \\
\text { Multikolinearit } \\
\text { as }\end{array}$ \\
\hline CR & 0.969 & $>0.10$ & $\begin{array}{l}1.03 \\
2\end{array}$ & $<10$ & $\begin{array}{l}\text { Tidak Terjadi } \\
\text { Multikolinearit } \\
\text { as }\end{array}$ \\
\hline
\end{tabular}

Sumber : Data Diolah 2019

4.2.1.3 Uji Autokorelasi (DurbinWatson)

Uji Autokeralasi dengan menggunakan Durbin-Watson(DW test). Berdasar tabel DW didapat dU sebesar 1.7932 , DW sebesar 2.090 dan 4 dU sebesar 2.2068 (dU<DW<4-Du), maka dapat disimpulkan bahwa tidak terjadi autokorelasi.

Tabel 5.: Hasil Uji Autokorelasi

\begin{tabular}{cccccc}
\hline $\begin{array}{c}\text { Durbin } \\
\text { Watson }\end{array}$ & $\mathrm{dL}$ & $\mathrm{Du}$ & 4-dL & 4-dU & Kesimpulan \\
\hline 2.090 & 1.6312 & 1.7932 & 2.3688 & 2.2068 & $\begin{array}{c}\text { Tida Terjadi } \\
\text { Autokorelasi }\end{array}$ \\
\hline
\end{tabular}

Sumber : Data Diolah 2019

\subsubsection{Uji Heteroskedastisitas (Spearman's Rho)}

Uji Heterokedastisitas penelitian ini menggunakan metode Spearman's Rho. Berdasar tabel di bawah, hasil uji menunjukan bahwa signifikansi >0.05 maka dapat dikatakan tidak terjadi heteroskedastisitas. 
Tabel 6.: Uji Heteroskedastisitas (Uji

\begin{tabular}{lccc} 
& \multicolumn{3}{c}{ Spearman's Rho $)$} \\
\hline Variabel & $\begin{array}{c}\text { Sig. } \\
(2 \\
\text { tailed })\end{array}$ & Std. & Keterangan \\
\hline ROA & 0.735 & $>0.05$ & $\begin{array}{c}\text { Tidak Terjadi } \\
\text { Heteroskedastisitas } \\
\text { Tidak Terjadi }\end{array}$ \\
SA & 0.762 & $>0.05$ & $\begin{array}{c}\text { Heteroskedastisitas } \\
\text { Tidak Terjadi }\end{array}$ \\
SIZE & 0.721 & $>0.05$ & $\begin{array}{c}\text { Heteroskedastisitas } \\
\text { Tidak Terjadi } \\
\text { Heteroskedastisitas } \\
\text { Tidak Terjadi }\end{array}$ \\
CR & 0.715 & $>0.05$ & \begin{tabular}{c} 
Heteroskedastisitas \\
\hline
\end{tabular} \\
\hline
\end{tabular}

Sumber : Data Diolah 2019

\subsubsection{Uji Regresi Linier Berganda 4.2.2.1 Model Regresi}

Tabel 7.: Hasil Uji Persamaan Linear

\begin{tabular}{ccc}
\multicolumn{2}{c}{ Berganda } \\
\hline & Model & $\begin{array}{c}\text { Unstandardized } \\
\text { Coefficients } \\
\text { B }\end{array}$ \\
\hline 1 (Constant) & .731 \\
ROA & .368 \\
NDTS & -17.544 \\
SA & .371 \\
Size & -.008 \\
CR & -.003 \\
\hline
\end{tabular}

Sumber : Data Diolah 2019

DER : $0.731+0.386$ ROA - 17.544 NDTS + 0.371 SA $-0.008 \quad$ SIZE $0.003 \mathrm{CR}$

Keterangan :

$\mathrm{Y}$

$\alpha$

Profitabilitas : profitabilitas (ROA)

NDTS : Non - debt tax shield

SA : Struktur Aktiva

Size : Ukuran Perusahaan

CR : Likuiditas (CR)

$\beta_{1} \beta_{2} \beta_{3} \beta_{4} \beta_{5} \quad$ : Koefisien Regresi

Parsial

e : Error

Artinya :

1. Nilai konstanta sebesar 0.731 , maka dapat disimpulkan apabila semua variabel independen memiliki nilai 0 atau konstan, maka nilai struktur modal sebesar 0.731 .

2. Nilai koefisien regresi variabel profitabilitas bernilai positif sebesar 0.386, menjelaskan bahwa setiap profitabilitas naik sebesar $1 \%$ akan diikuti peningkatan struktur modal sebesar 0.386, dengan asumsi nilai koefisien variabel independen lainnya dianggap tetap atau sama dengan nol.

3. Nilai koenfisien regresi variabel nondebt tax shield sebesar bernilai negatif -17.544 , menjelaskan bahwa setiap non debt tax shield naik1\% akan diikuti penurunan struktur modal sebesar -17.544, dengan asumsi nilai koefisien variabel independen lainnya dianggap tetap atau sama dengan nol.

4. Nilai koefisien regresi variabel struktur aktiva sebesar 0.371, menjelaskan bahwa setiap struktur aktiva naik sebesar $1 \%$ akan diikuti peningkatan struktur modal sebesar 0.371 , dengan asumsi nilai koefisien variabel independen lainnya dianggap tetap atau sama dengan nol.

5. Nilai koefisien regresi variabel ukuran perusahaan sebesar -0.008 , menjelaskan bahwa setiap ukuran perusahaan naik $1 \%$ akan diikuti penurunan struktur modal sebesar 0.008 , dengan asumsi nilai koefisien variabel independen lainnya dianggap tetap atau sama dengan nol.

6. Nilai koefisien regresi variabel likuiditas sebesar -0.003 , menjelaskan bahwa setiap likuiditas naik $1 \%$ akan diikuti penurunan struktur modal sebesar -0.003 , dengan asumsi nilai keofisien variabel independen lainnya dianggap tetap atau sama dengan nol.

\subsubsection{Uji Kelayakan Model (UjiF- Statistik)}

Uji simultan menggunakan uji FStatistik. Berdasar tabel dibawah, hasil yang diperoleh bahwa F Hitung > nilai F tabel dan sig. Nilai <0.05, maka $\mathrm{H} 1$ diterima dan $\mathrm{HO}$ di tolak. Hal ini berarti bahwa variabel Profitabilitas, Non debt tax shield, struktur aktiva, ukuran 
perusahaan dan likuiditas secara simultan memengaruhi struktur modal.

\begin{tabular}{cccccc}
\multicolumn{6}{c}{ Tabel 8. Hasil Uji F } \\
\hline Model & $\mathrm{F}_{\text {hitung }}$ & $\mathrm{F}_{\text {tabel }}$ & Sig $_{\text {hit }}$ & Std. & Hasil \\
\hline Regression & 9.432 & 2.45 & 0.000 & $<0.05$ & $\begin{array}{c}\text { Model } \\
\text { Layak }\end{array}$
\end{tabular}

Sumber : Data Diolah 2019

\subsubsection{Uji Hipotesis (Uji t)}

Uji Hipotesis menggunakan uji t. Berdasar tabel dibawah ini, jika nilai $t$ hitung >t tabel dan Sig <0.05, berarti variabel secara parsial mempengaruhi variabel dependen.

Tabel 9.Hasil Uji t

\begin{tabular}{cccccc}
\hline $\begin{array}{c}\text { Hipote } \\
\text { sis }\end{array}$ & $\begin{array}{c}\mathrm{t}_{\text {hitun }} \\
\mathrm{g}\end{array}$ & $\mathrm{t}_{\text {tabel }}$ & Sig. & Std. & $\begin{array}{c}\text { Kesimpu } \\
\text { lan }\end{array}$ \\
\hline ROA & .87 & 1.976 & 0.3 & $<0$. & Ditolak \\
& 4 & 0 & 84 & 05 & \\
NDTS & - & 1.979 & 0.0 & $<0$. & Diterima \\
& 5.1 & 60 & 00 & 05 & \\
& 94 & & & & \\
SA & 4.7 & 1.979 & 0.0 & $<0$. & Diterima \\
& 01 & 60 & 00 & 05 & \\
SIZE & - & 1.979 & 0.1 & $<0$. & Ditolak \\
& 1.3 & 60 & 70 & 05 & \\
& 80 & & & & \\
CR & - & 1.979 & 0.7 & $<0$. & Ditolak \\
& 0.3 & 60 & 29 & 05 & \\
& 47 & & & & \\
\hline
\end{tabular}

Sumber : Data Diolah 2019

\subsubsection{UjiKoefisien Determinasi $R^{2}$} Hasil nilai Adjusted R2 diperoleh 0,249 atau 24,9\% berarti bahwa persentasi kontribusi variabel independen dalam mempengaruhi struktur modal dan sisanya $75.1 \%$ merupakan pengaruh dari variabel lain yang tidak termasuk dalam penelitian ini.

Tabel 10.Hasil Uji Koefisien Determinasi $\mathrm{R}^{2}$

\begin{tabular}{cc}
\hline $\begin{array}{c}\text { Adjusted R } \\
\text { Square }\end{array}$ & Keterangan \\
\hline 0.249 & Berpengaruh Sebesar 24.9\% \\
\hline
\end{tabular}

Sumber : Data Diolah 2019

\section{PEMBAHASAN}

a. Pengaruh profitabilitas terhadap struktur modal

Berdasar hasil uji hipotesisi ke satu variabel profitabilitas tidak berpengaruh terhadap struktur modal. Hal ini menunjukan ketika profitabilitas perusahaan naik, maka struktur modal akan turun. Diindikasikan perusahaan yang memiliki tingkat profitabilitas tinggi akan mengurangi ketergantungan modal dari pihak eksternal dan menggunakan dana internal terlebih dulu. Hal ini sesuai dengan pecking order theory dimana perusahaan lebih menyukai penggunaan dana dari internal terlebih dahulu dari pada pendanaan dari eksternal atau hutang. Penelitian ini sejalan dengan (Thabet, Shawtari, Mohammed, \& Ali, 2017) dan (Putri \& Dillak, 2018). Namun hasil kontradiktif dengan penelitian (Goh, Tai, Rasli, Tan, \& Zakuan , 2018), (Andayani \& Suardana, 2018), dan (Sudiyanto, Irmawati, Puspitasari, \& Nurhayati, 2019).

\section{b. Pengaruh Non-debt tax shield terhadap struktur modal}

Hasil pengujian hipotesis ke dua, hasil penelitian menunjukan bahwa nondebt tax shield berpengaruh terhadap struktur modal. Non debt tax shield merupakan pengurangan pajak yang bukan berasal dari hutang, melainkan berupa depresiasi aktiva tetap dan amortisasi perusahaan. Hal ini ditunjukan dengan Semakin tinggi non debt tax shield maka perusahaan akan mengurangi penggunaan hutangnya, karena pengurangan pajak yang berasal dari bunga pinjaman bisa diganti dengan berupa pengurangan pajak yang berasal dari depresiasi dan amortisasi. Penelitian ini sejalan dengan penelitian (Miraza \& Munirudin, 2017 ), (Goh, Tai, Rasli, Tan, \& Zakuan , 2018), dan (Dewi \& Dana, 2017), namun hasil kontradiktif dengan penelitian (Wulandari \& Artini, 2019), (Putri \& Dillak, 2018). 


\section{c. Pengaruh struktur aktiva terhadap struktur modal \\ Berdasar hasil pengujian} hipotesis ke tiga, hasil penelitian ini menunjukan bahwa struktur aktiva berpengaruh terhadap struktur modal. hal ini menujukan bahwa semakin tinggi struktur aktiva (aset) perusahaan, perusahaan akan cenderung menekan penggunaan dana dari eksternal perusahaan, pendanaan eksternal disini merupakan hutang. Penggunaan dana dari eksternal hanya akan digunakaan pada saat pendanaan internal tidak mencukupi atau perusahaan sedang kekurangan modal sesuai dengan Pecking Order Theory. Penelitian ini sejalan dengan (Andayani \& Suardana, 2018), (Kartika Sari, Titisari, \& Nurlaela, 2018), dan (Sudiyanto, Irmawati, Puspitasari, \& Nurhayati, 2019), namun hasil kontradiktif dengan penelitian (Ahmad, Lestari, \& Dalimuthe, 2017), (Wirawan, 2017).

\section{d. Pengaruh ukuran perusahaan terhadap struktur modal}

Hasil pengujian hipotesis ke empat, penelitian menunjukkan hasil ukuran perusahaan tidak berpengaruh terhadap struktur modal. hal ini ditunjukan bahwa semakin besar perusahaan berarti sumber pendanaan internal perusahaan tersebut juga tinggi, sehingga perusahaan tidak begitu membutuhan pendanaan dari eksternal atau hutang pernyataan ini sesuai pecking order theory. Penelitian ini sejalan dengan hasil penelitian (Putri \& Dillak, 2018), (Wirawan, 2017), dan (Kartika Sari, Titisari, \& Nurlaela, 2018), namun kontradiktif dengan penelitian (Ahmad, Lestari, \& Dalimuthe, 2017), (Wulandari \& Artini, 2019) dan (Goh, Tai, Rasli, Tan, \& Zakuan, 2018).

\section{e. Pengaruh likuiditas terhadap struktur modal}

Berdasar hasil pengujian hipotesis ke lima, hasil penelitian ini menunjukan bahwa likuiditas tidak berpengaruh terhadap struktur modal. Hal ini menunjukan apabila makin tinggi kemampuan perusahaan dalam melunasi kewajiban lancarnya, dapat dikatakan kondisi perusahaan sehat. Namun Apabila likuiditas tidak tercapai maka perusahaan harus melakukan pendanaan lewat eksternal, karena pendanaan internal belum sepenuhnya memenuhi untuk kebutuhan operasional perusahaan, maka pemenuhan struktur modal juga tidak tercapai. Hasil ini tidak cocok dengan pecking order theory yang menyatakan bahwa perusahaan akan lebih mengndalkan penggunaan dana internal dahulu dibandingkan penggunaan dana eksternal alias hutang. Penelitian ini sejalan dengan hasil penelitian (Wirawan, 2017), (Dewi \& Dana, 2017), dan (Andayani \& Suardana, 2018), namun hasil kontradiktif dengan penelitian (Ahmad, Lestari, \& Dalimuthe, 2017), (Sudiyanto, Irmawati, Puspitasari, \& Nurhayati, 2019).

\section{KESIMPULAN DAN SARAN 6.1.Saran}

Berdasar hasil uji dan pembahasan, tujuan penelitian ini adalah untuk menguji dan menganalisis pengaruh profitabilitas, non-debt tax shield, struktur aktiva, ukuran perusahaan dan likuiditas terhadap struktur modal. maka dapat di tarik kesimpulan bahwa hasil uji secara parsial variabel non-debt tax shield dan struktur aktiva berpengaruh terhadap struktur modal sedangkan pada variabel profitabilitas, ukuran perusahaan dan likuiditas tidak berpengaruh terhadap struktur modal. dan kesimpulan hasil secara simultan menunjukan bahwa variabel profitabilitas, non-debt tax shield, struktur aktiva, ukuran perusahaan dan likuiditas secara bersama sama memiliki pengaruh secara simultan terhadap struktur modal.

Keterbatasan penelitian ini adalah (1) Nilai adjusted $\mathrm{R}^{2}$ yang hanya sebesar 0.249 atau $24.9 \%$. Nilai ini tergolong rendah karena menunjukan bahwa 
profitabilitas, non-debt tax shield, struktur aktiva, ukuran perusahaan dan likuiditas hanya mampu mempengaruhi dan menjelaskan struktur modal sebesar $21.5 \%$ dan $71.5 \%$ dijelaskan oleh variabel lain (selain profitabilitas, nondebt tax shield, struktur aktiva, ukuran perusahaan dan likuiditas) (2) Variabel yang digunakan terbatas hanya 5 variabel saja dan tahun penelitian hanya 4 tahun.

Berdasar keterbatasan, saran untuk penelitain selanjutnya 1) Untuk bisa menambah variabel seperti resiko bisnis, Pertumbuhan penjualan supaya mampu memperkuat variabel yang mempengaruhinya. 2) Diharapkan mampu menampah tahun penelitian menjadi 5 tahun dan meneliti pada perusahaan yang berbeda.

\section{DAFTAR PUSTAKA}

Ahmad, G. N., Lestari, R., \& Dalimuthe, S. (2017). Analysis Of Effect Of Profitability, Assets Structure, Size Of Companies, And Liquidity To Capital Structures In Mining Companies Listed In Indonesia Stock Exchange Period 2012 - 2015 . Jurnal Riset Manajemen Sains Indonesia (Jrmsi) Vol.8, No.2, 339-354.

Andayani, I. K., \& Suardana, K. A. (2018). Pengaruh Profitabilitas, Likuiditas, Pertumbuhan Penjualan, Dan Struktur Aktiva Pada Struktur Modal. E-Jurnal Akuntansi Universitas Udayana Vol 24, No. 1, 370-298.

Ardiansyah, F. D., \& Srimindarti, C. (2018). Determinanstruktur Modal Padaperusahaan Property Dan Real Estate Yang Terdaftar Pada Bei Periode Tahun 20122016. Prosiding Sendi_U, 581588.

Ariani, N. A., \& Wiagustini, N. P. (2017). Faktor Faktor Yang Mempengaruhi Struktur Modal Perusahaan Property \&Real
Estate Yang Terdaftar Di Bei . EJurnal Manajemen Unud Vol. 6, No. 6, 3168-3195.

Brigham, E. F., \& Houston, J. F. (2011). Dasar-Dasar Manajemen Keuangan, Edisi 11 Buku 2. Jakarta : Salemba Empat.

Brigham , E. F., \& Weston, J. F. (2005:175). Dasar Dasar Manajemen Keuangan Edisi Ke Sembilan. Jakarta: Erlangga.

Dewi, F. L., Susyanti, J., \& Salim, A. (2018). Pengaruh Ukuran Perusahaan, Pertumbuhan Aset, Profitabilitas Dan Pajak Penghasilan Badan Terhadap Struktur Modal (Studi Kasus Pada Perusahaan Kosmetik Yang Terdaftar Di Bei Tahun 20132017) . E - Jurnal Riset Manajemen, 102-112.

Dewi, T. N., \& Dana, I. (2017). Pengaruh Growth Opportunity, Likuiditas, Non-Debt Tax Shield, Dan Fixed Asset Ratio Terhadap Struktur Modal. E-Jurnal Manajemen Unud Vol. 6, No. 2, 772-801.

Goh, C. F., Tai, W. Y., Rasli, A., Tan, O. K., \& Zakuan , N. (2018). The Dterminants Of Capital Structure : Evidance From Malaysian Companies. International Journal of Supply Chan Management Vol. 7, No. 3, 225230.

Kartika Sari, N. I., Titisari, K. H., \& Nurlaela, S. (2018). The Effect Structure Of Assets, Liquidity, Firm Size And Profitability Of Capital Structure. Ictes, 107-117.

Krisnanda , H. P., \& Wiksuana , I. B. (2015). Pengaruh Ukuran Perushaan, Pertumbuhan Penjualan, Dan Non Debt Tax Shield Terhadap Struktur Modal Pada Perusahaan Telekomunikasi Di Bursa Efek Indonesia. E-Jurnal Manajemen Vol. 4, No. 5, 134-1451. 
Miraza, C. N., \& Munirudin, S. (2017). Pengaruh Kepemilikan Institusioanal, Kepemilikan Manajerial, Variabilitas Pendapatan, Corporate Tax Rate, Dan Non Debt Tax Shield Terhadap Struktur Modal Pada Perusahaan Manufaktur Yang Terdafatar Di Bei 2011-2015. Jurnal Ilmiah Mahasiswa Ekonomi Akuntansi (Jimeka) Vol.2 , No. 3, 73-85.

Munawir. (2004 : 33). Analisa Laporan Keuangan, Edisi Keempat, Cetakan Ketigabelas. Yogjakarta: Liberty.

Nainggolan , M. V., Azlina, N., \& Julita. (2017). Pengaruh Kebijakan Deviden, Profitabilitas , Ukuran Perusahaan, Resiko Bisnis, Cash Holding, Kontrol Kepemilikan, Dan Non Debt Tax Shield Terhadap Struktur Modal Pada Perusahaan Manufaktur Yang Terdaftar Di Bursa Efek Indonesia (Periode 2011-2014). Jom Fekom Vol. 4, No. 1, 528542.

Putri, A. I., \& Dillak, V. J. (2018). Pengaruh Pertumbuhan Penjualan, Ukuran Perusahaan, Profitabilitas, Dan Non-Debt Tax Shield Terhadap Struktur Modal ( Studi Kasus Pada Perusahaan Barang Jonsumsi Yang Terdaftar Di Bursa Efek Indonesia Periode 2014-2017). Journal Accounting And Finance Vol. 2, No. 2, 41-50.

Sudiyanto, B., Irmawati, Puspitasari, E., \& Nurhayati, I. (2019). Capital Structure : The Factors That Influence It (Empiorical Study On Manufakturing Campanies In Indonesia Stick Exchange ). Prosiding Sendi, 518-525.

Sundari, D., \& Susilowibowo, J. (2016 ). Pengaruh Ukuran Perusahaan Dan Non-Debt Tax Shield Terhadap Struktur Modal Pada
Perusahaan Sektor Keuangan. Jurnal Ilmu Manajemen Vol. 1, No. 1, 1-12.

Tangkulung, E. G., Murni, S., \& Untu, V. N. (2019). Pengaruh Asset Size Dan Profitabilitas Terhadap Struktur Modal . Jurnal Emba Vol.7, No. 1, 771-780.

Thabet, O. B., Shawtari, F. A., Mohammed, A. A., \& Ali, F. (2017). Capital Structure Of Malaysian Shraiah Complimant Firms. Jkau : Islamic Econ, Vol 30, No. 1, 105-116.

Van Horne, J. C., \& Wachowich, J. M. (2001). Findamental of Financial Management. New Jersy: Prentice Hall.

Wirawan, P. A. (2017). Pengaruhstruktur Aktiva, Profitabilitas, Ukuran Perusahaan Dan Likuiditas Terhadap Struktur Modal Pada Perusahaan Sektor Barang Konsumsi Yang Terdaftar Di Bursa Efek Indonesia Periode Tahun 2014-2015. Jurnal Pendidikan Ekonomi Undiksha Vol. 9, No. 1, 1-10.

Wiyono, G., \& Kusuma, H. (2017 : 173). Manajemen Keuangan Lanjutan . Yogyakarta: Upp Stim Y.

Wulandari, N. I., \& Artini, L. S. (2019). Pengaruh Likuiditas, Non Debt Tax Shield, Ukuran Perusahaan Dan Pertumbuhan Penjualan Terhadap Struktur Modal. EJurnal Manajemen Vol. 8, No. 6, 3560-3590.

Yoshendy, Andi, \& Dkk. (2015). Analisis Faktor Faktor Yang Mempengaruhi Struktur Modal Perusahaan Barang Konsumsi Di Bei Tahun 2002-2011. Jurnal Bisnis Dan Manajemen16(1), 47-59. 
